\title{
LASER GLAZING OF PLASMA-SPRAYED ZIRCONIA COATINGS
}

\author{
D. CARRON, L. BEYLAT, T. PUIG* and S. HAGEGE** \\ ETCA CREA/PS, 16 bis av. Prieur de la Côte d'Or, F-94114 Arcueil cedex, France \\ *DRET, SDR/G8, 26 bd. Victor, F-00460 Armées, France \\ ${ }^{* *} C E C M / C N R S, 15$ rue Georges Urbain, F-94400 Vitry sur Seine, France
}

\begin{abstract}
The effects of surface melting produced by a high-power continuous wave $\mathrm{CO}_{2}$ laser on the structure of a $8 \%$ yttria partially stabilized zirconia plasma-sprayed coating are reported. The influence of interaction time was studied. Shiny surfaces were produced with an important reduction of superficial porosity at $10.7 \mathrm{~kW} / \mathrm{cm}^{2}$ and values of interaction time 12.5 to $25 \mathrm{~ms}$. However a problem of surface unhomogeneity occured.
\end{abstract}

\section{1- Introduction:}

Plasma-sprayed zirconia coatings are widely used to insulate hot-area components of gas turbine and diesel engines [1]. In spite of their performances, the durability of these thermal barrier coatings (TBCs) at operating conditions is greatly affected by extreme thermal cycling and severe environment encountered $[2,3]$.

Laser glazing with a continuous wave $\mathrm{CO}_{2}$ laser can improve their behavior as revealed by previous studies $[4,5,6,7]$. This treatment was expected to enhance the high-temperature corrosion resistance of coatings and to offer an aerodynamic benefit by decreasing the porosity and improving the surface finish. It was also expected to made the material more strain-tolerant during thermal cycling by segmentation of the zirconia coating wich may accommodate thermal stresses [8].

The present paper summarizes the results of an investigation using a high power continuous wave $\mathrm{CO}_{2}$ laser to melt a part of a 8\% yttria partially stabilized zirconia plasma-sprayed layer. Motivation for working with a high power beam shaped laser was to obtain a large and homogeneous surface treated by a single pass.

\section{2- Experimental procedure:}

Duplex $\mathrm{ZrO}_{2}-8 \mathrm{wt} . \% \mathrm{Y}_{2} \mathrm{O}_{3} / \mathrm{MCrAlY}$ thermal barrier coatings were prepared by plasma spraying on Hastelloy X. The substrate was sand-blasted and a 100-150 $\mu \mathrm{m}$ thick MCrAlY bond coat was first applied (air plasma-sprayed NiCrAlY bond coat or low pressure plasma-sprayed NiCoCrAlYTa bond coat). The 350-400 $\mu \mathrm{m}$ thick zirconia top coat was then deposited by air plasma spraying of $8 \mathrm{wt}$. \% yttria partially stabilized zirconia powder.

Laser surface melting was achieved by the continuous wave $25 \mathrm{~kW} \mathrm{CO}_{2}$ laser $(\lambda=10.6 \mu \mathrm{m})$ of ETCA / CREA LA. Beam shaping was provided by a kaleidoscope $5 \times 15 \mathrm{~mm}$. The power density was $10.7 \mathrm{~kW} / \mathrm{cm}^{2}$ at the cavity exit and the interaction time was between 10 and $40 \mathrm{~ms}$. Plane specimens of $40 \times 60 \times 3 \mathrm{~mm}$ mounted on a spinning arm were treated at different speeds. The lasered coatings were characterized by optical and scanning electron microscopy, electron microprobe and X-ray diffraction. 


\section{3- Results and discussion:}

3.1- General features of laser-treated coatings:

As-sprayed coatings have a highly porous and microcracked structure. Laser surface melting was found to produce tracks ( $15 \mathrm{~mm}$ width) with a shiny surface and an important reduction of superficial porosity. These differences between as-lasered and as-sprayed areas are clearly illustrated in Fig. 1.

However, there were numerous large diameter craters emerging at the material surface. It is suggested these craters were due to degassing through the molten ceramic layer of air trapped during the plasma spraying of zirconia [8, 9]. At the quick stage cooling, the phenomenon stopped thus leaving bubbles within the laser-treated layer (Fig. 2-a). Consequently the rapidly solidified laser-treated layer was not completly densified.

In transverse section, the laser-melted layer showed a columnar structure (Fig. 2-a). The corresponding surface microstructure exhibited fine polygonal cells (Fig. 2-b). The laser-treated regions were also segmented by a network of cracks resulting from thermal shock and from the shrinkage due to the reduction of porosity during cooling $[7,8]$. The corresponding transverse cracks went through the entire melted layer.

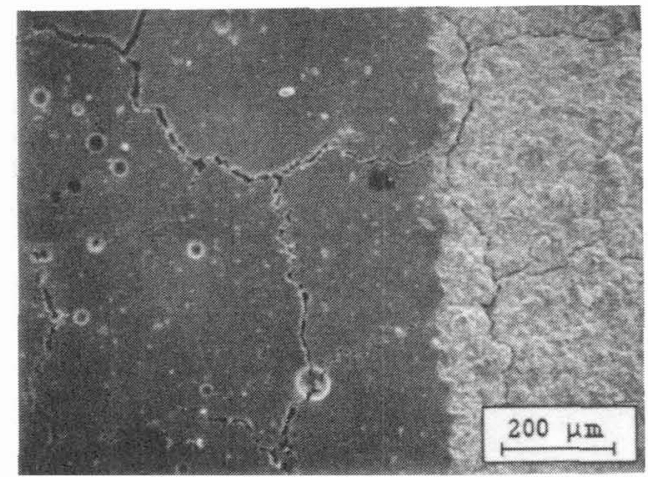

Fig. 1: SEM imugi of the interface between as-lasered and as-sprayed areas $\left(\mathrm{ZrO}_{2} / \mathrm{NiCoCrAlYTa}\right.$ sample, $\left.13 \mathrm{~ms}\right)$
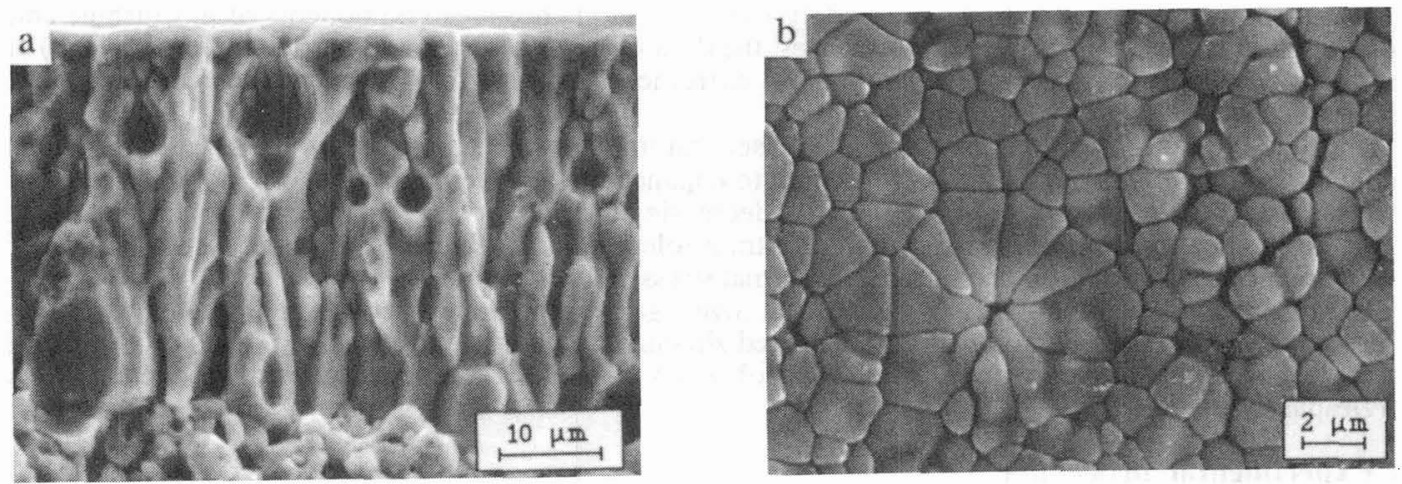

Fig. 2: SEM image of the melted ceramic layer ( $\mathrm{ZrO}_{2} / \mathrm{NiCrAlY}$ sample)

a) transverse section showing columnar structure and bubbles trapped in the layer $(25 \mathrm{~ms})$

b) plan view showing fine polygonal cells $(12.5 \mathrm{~ms})$

3.2- Influence of the interaction time:

All the following results concerning the influence of the interaction time were obtained using $\mathrm{ZrO}_{2}$ $8 \mathrm{wt} . \% \mathrm{Y}_{2} \mathrm{O}_{3} / \mathrm{NiCrAlY}$ coatings. The interaction time was given by $\mathrm{t}=1 / \mathrm{v}$ where 1 an $\mathrm{v}$ were the length of the irradiated surface $(5 \mathrm{~mm})$ and the linear speed of specimen respectively. 
Lasered tracks with improved surface finish were obtained with interaction time between 12.5 and 25 $\mathrm{ms}$. The corresponding melted depths were between 15 and $40 \mu \mathrm{m}$. Thicker laser-melted layers showed detrimental longitudinal cracks wich may lead to spalling [10].

It was observed that the vertical cracks length, the cell size of segmentation (i.e the average size of the crack network spacing) and the melted depth increase with increasing interaction time (Fig. 3). In the range of high interaction times (up to $40 \mathrm{~ms}$ ), laminar cracking appeared. These results agree with Jeandin et al. investigations on a similar TBC [8]. It was also showed that the cell size of columnar microstructure increases with increasing interaction time and that for the same laser track there is no influence of position (center, edge) for the cell size of segmentation.
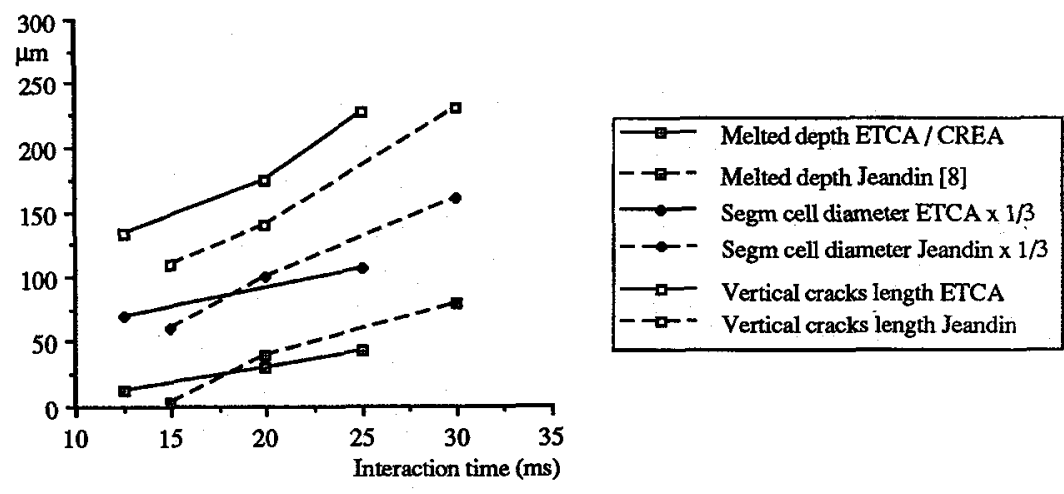

Fig. 3: Influence of interaction time at $10.7 \mathrm{~kW} / \mathrm{cm}^{2}\left(\mathrm{ZrO}_{2} / \mathrm{NiCrAlY}\right.$ sample $)$

3.3 Phases present in the samples:

$X$-ray diffraction was used to determinate the amounts of monoclinic, tetragonal $t$ and cubic phases in plasma-sprayed zirconia coatings before and after laser treatment [11]. The monoclinic phase which was present $(<2 \mathrm{wt} . \%)$ in as-sprayed layers was not detected in lasered coatings where only non transformable high- $\mathrm{Y}_{2} \mathrm{O}_{3}$-content tetragonal $t^{\prime}$ phase was found. The cubic phase was not detected before and after laser treatment.

As a result of electron microprobe investigation, the laser melting seems to make the yttrium content more homogeneous then it was in as-sprayed layers.

3.4 Distribution of craters and roughness:

In order to realize thermal cyclic tests, $\mathrm{ZrO}_{2}-8$ wt. $\% \mathrm{Y}_{2} \mathrm{O}_{3}$ coatings with performing NiCoCrAlYTa bond coat were laser-treated. Comparison with the treatment of $\mathrm{ZrO}_{2}-8$ wt.\% $\mathrm{Y}_{2} \mathrm{O}_{3} /$ NiCrAlY coatings in the same conditions was found to give different results. Particularly, the interaction time required to obtain a same melted depth was shorter in the case of $\mathrm{ZrO}_{2} /$ NiCoCrAlYTa coatings. This difference was probably due to an adjustement of the laser beam done between the two series of treatment. Using a calorimeter may solve this problem by controlling the real input energy.

An other difficulty was the control of the homogeneity of lasered surfaces. $\mathrm{ZrO}_{2} / \mathrm{NiCoCrAlYTa}$ coatings laser melted with an interaction time of $13 \mathrm{~ms}(40 \mu \mathrm{m}$ of melted depth) exhibited two different zones in surface (Fig. 4).The first zone was well-glazed, having a lower roughness than the as-sprayed coatings. The second zone was rough and its value of roughness was much more important than the value of the as-sprayed coatings. Scanning electron micrographs of these two zones showed the considerable influence of degassing upon surface morphology. There were many craters emerging at the surface of the rough zone, several of them being over $100 \mu \mathrm{m}$ in diameter (Fig. 5-a). These craters were deep and often went through the entire melted layer creating important depressions wich increased the roughness value. By comparison the glazed zone exhibited a smoothened surface where only rare little craters appeared (Fig. 5-b) thus lowering the roughness value and improving the surface finish. The reasons of formation of these two different zones are not well understood but it might be attributed to a thermal problem during laser processing. 


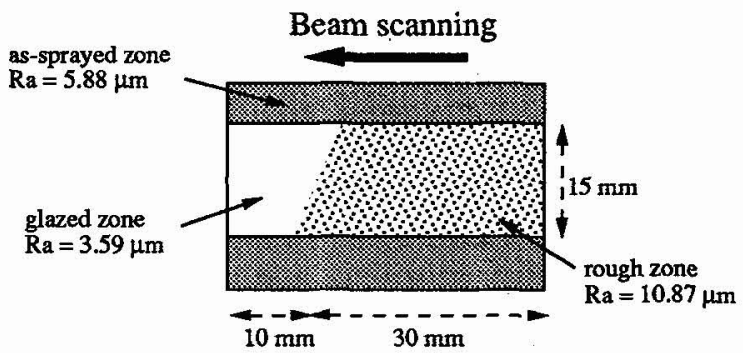

Fig. 4: Surface of a $\mathrm{ZrO}_{2}$ / NiCoCrAlYTa sample laser-treated with an interaction time of $13 \mathrm{~ms}$
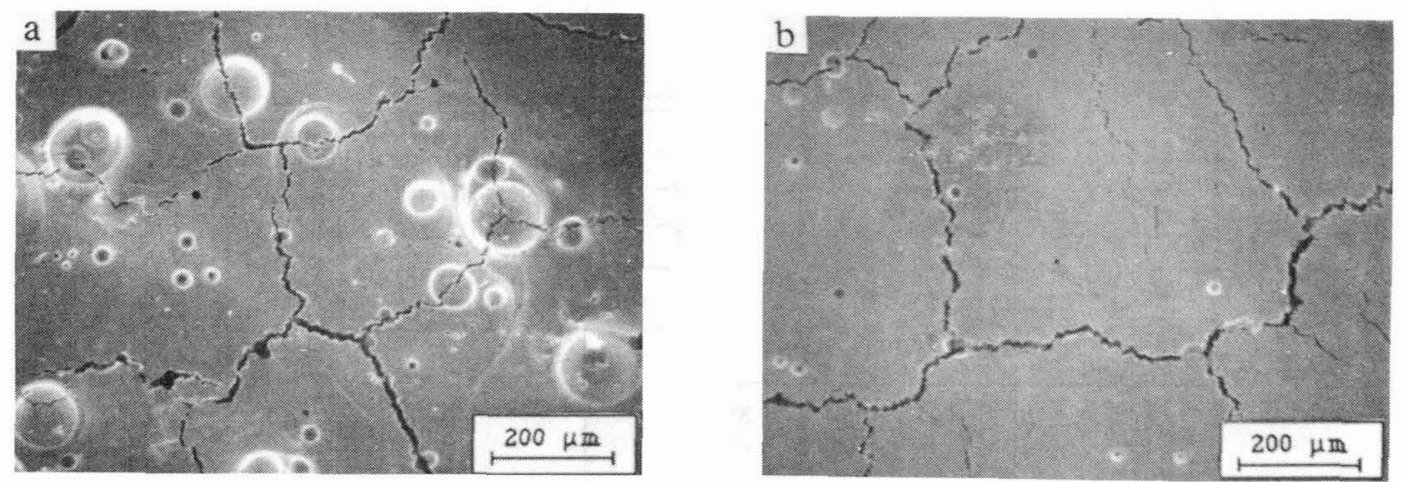

Fig. 5: SEM image of the surface of a $\mathrm{ZrO}_{2} /$ NiCoCrAlYTa sample laser-treated with an interaction time of $13 \mathrm{~ms}$ (a-rough zone,b-glazed zone)

\section{Conclusion:}

This work has shown that surface melting with a high power continuous wave $\mathrm{CO}_{2}$ laser on an yttria partially stabilized zirconia plasma-sprayed coating is capable of producing tracks with a shiny surface and an important reduction of superficial porosity. Influence of interaction time was studied and results agreed with previous works. However an unhomogeneity of lasered surface was observed and only a part of it was really glazed with a low roughness value. Understanding the reasons of this phenomenon and producing entire glazed specimens will be the aim of future studies. Preliminary promising thermal cycling tests will be continued to characterize properties of laser melted coatings.

\section{Acknowledgements}

This work is supported by STPA. We thank Mr Morbioli, SNECMA, for the supply of plasma-sprayed samples and realization of roughness measurements.

\section{References}

[1] D.J. Wortman, B.A. Nagaraj and E.C. Duderstadt, Mater. Sci. Eng. A121 (1989) 433

[2] B.C. Wu, E. Chang, S.F. Chang and D. Tu, J. Am. Ceram. Soc. 72 [2] (1989) 212

[3] I. Kvernes and S. Forseth, Mater. Sci. Eng. 88 (1987) 61

[4] R.A. Miller and C.C. Berndt, Thin Solid Films 119 (1984) 195

[5] I. Zaplatynsky, Thin Solid Films 95 (1982) 275

[6] F.S. Galasso and R. Veltri, Ceramic Bull. 62 [2] (1983) 253

[7] A. Petitbon, D. Guignot, U.Fisher and J.M. Guillemot, Mater. Sci. Eng. A121 (1989) 545

[8] M. Jeandin, D. Albert, R. Martinou, P. Lechervy and D. Varela, Proc. 4th CISFFEL 26-30 Sept. 88 Cannes France (1988) 663

[9] K. Mohammed Jasim, R.D. Rawlings and D.R.F. West, J. Mater. Sci. 26 (1991) 909

[10] R. Sivakumar and B.L. Mordike, Surf. Eng. 4 [2] (1988) 127

[11] N. Iwamoto and N. Umesaki, Thin Solid Films 127 (1985) 129 